\title{
Synthesis and structure of dinitrosyl iron complexes with secondary thiolate bridging ligands $\left[\mathrm{Fe}_{2}\left(\mu-\mathrm{SCHR}_{2}\right)_{2}(\mathrm{NO})_{4}\right], \mathrm{R}=\mathrm{Me}, \mathrm{Ph}$
}

\author{
P.B. Davidovich ${ }^{\text {a,* }}$, V.V. Gurzhiy ${ }^{\text {b }}$, N.A. Sanina ${ }^{c}$, A.V. Shchukarev ${ }^{\text {d }}$, A.V. Garabadzhiu ${ }^{\text {a }}$, A.N. Belyaev ${ }^{a}$ \\ ${ }^{a}$ St. Petersburg State Technological Institute, 26, Moskovskii av., St. Petersburg 190013, Russia \\ ${ }^{\mathrm{b}}$ St. Petersburg State University, 7/9, University emb., St. Petersburg 199034, Russia \\ ' Institute of Problems of Chemical Physics, Russian Academy of Sciences, 1, Acad. Semenov av., Chernogolovka, 142432 Moscow Region, Russia \\ d Umeå University, Umeå SE-901 87, Sweden
}

\section{A R T I C L E I N F O}

\section{Article history:}

Received 21 December 2014

Accepted 7 February 2015

Available online 17 February 2015

\section{Keywords:}

Crystal structure

Thiolate ligands

Dinitrosyl iron complex

Nitric oxide donor

DFT calculations

\begin{abstract}
A B S T R A C T
New dinitrosyl iron complexes of binuclear structure $\left[\mathrm{Fe}_{2}\left(\mu-\mathrm{SCHMe}_{2}\right)_{2}(\mathrm{NO})_{4}\right]$ and $\left[\mathrm{Fe}_{2}\left(\mu-\mathrm{SCHPh}_{2}\right)_{2}(\mathrm{NO})_{4}\right]$ were first synthesized employing new method from $\mathrm{Fe}(\mathrm{CO})_{5}$, corresponding thiol, and EtONO. Complexes structures were determined by XRD technique. DFT calculations were performed to probe the cisconformer structures in gas and solution phases. NO donor ability of the complex with isopropyl thiolate ligand was studied.
\end{abstract}

() 2015 Elsevier Ltd. All rights reserved.

\section{Introduction}

The interest to iron-thiolate coordination compounds is mainly due to their abundance in nature in the form iron-sulfur clusters $\left(\mathrm{Fe}_{x} \mathrm{~S}_{y}\right)$ responsible for cellular redox status [1]. Today the redox modulation with metal complexes is suggested to be nextgeneration therapy in cancer [2].

Endogenously treatment of $\mathrm{Fe}_{x} \mathrm{~S}_{y}$ clusters with NO can transform these clusters into dinitrosyl iron complexes (DNIC) [3,4]. In turn DNICs can affect the redox state of the cell via the reactions with free cysteine residues, leading to the formation of unstable $S$-nitrosocysteine derivatives that decompose to form disulfides $[5,6]$. DNICs (as well as $S$-nitroso thiols) considered to be the depot of NO in living cells $[7,8]$. Binuclear DNICs $\left[\mathrm{Fe}_{2}(\mu-\mathrm{SR})_{2}(\mathrm{NO})_{4}\right]$ (called Roussin's red salt esters - RRSE) are naturally occurring complexes that are formed in vivo by the nitrosylation of [4Fe-4S] iron-sulfur clusters [9]. Synthetically obtained complexes can serve as NO source after dissolution in aqueous media [10] or after photo-activation [11]. Today synthetic DNICs are suggested for use in medicine as NO donor pro-drugs [12].

\footnotetext{
* Corresponding author.

E-mail address: davidovich.pavel@technolog.edu.ru (P.B. Davidovich).
}

Different synthetic ways are described for the dinuclear RRSE preparations: nitrosylation of $\mathrm{Fe}(\mathrm{II})$ and thiolate mixed solution with $\mathrm{NO}^{\mathrm{g}}$ [13]; S-alkylation of Roussin's red salt $\mathrm{Na}_{2}\left[\mathrm{Fe}_{2}(\mu-\mathrm{S})_{2}\right.$ $(\mathrm{NO})_{4}$ ] [14]; substitution reactions of DNICs thiosulfate bridging ligands $\mathrm{Na}_{2}\left[\mathrm{Fe}_{2}\left(\mu-\mathrm{SSO}_{3}\right)_{2}(\mathrm{NO})_{4}\right]$ with other thiolates [15]; reaction of $\mathrm{Fe}(\mathrm{NO})_{2}(\mathrm{CO})_{2}$ with thiols [12]; S-oxidation of the mononuclear species $\left[\mathrm{Fe}(\mathrm{SR})_{2}(\mathrm{NO})_{2}\right]^{-}[16]$.

Today structural data for binuclear RRSEs $\left[\mathrm{Fe}_{2}(\mu-\mathrm{SR})_{2}(\mathrm{NO})_{4}\right]$ are available with aliphatic [3,17], aromatic [18,19], peptide bound [20], and inorganic [21,22] substituents. Different "aliphatic" DNICs with primary $[23,24]$ and tertiary $[25,26]$ thiolate ligands are known, yet binuclear DNICs with secondary thiols $\left(\mathrm{R}_{2} \mathrm{CH}-\mathrm{SH}\right)$ were not earlier structurally characterized by X-ray diffraction analysis. The $n$-propyl DNIC $\left[\mathrm{Fe}_{2}\left(\mu-\mathrm{S}-{ }^{n} \mathrm{Pr}\right)_{2}(\mathrm{NO})_{4}\right]$ was synthesized and its structure was determined by XRD crystallography to be centrosymmetric by Ref. [23]. A complex with benzyl substituent at the sulfur bridging atom was described by Lippard and co-workers [19] and with the ethyl substituent, by Lu et al. [27].

The structure and dynamic properties of these compounds should be understood as they are suggested as prodrugs for the delivery of nitric oxide [12]. Herein we describe the crystal structure, DFT calculations of $\left[\mathrm{Fe}_{2}\left(\mu-\mathrm{SCHMe}_{2}\right)_{2}(\mathrm{NO})_{4}\right]$ (I) and $\left[\mathrm{Fe}_{2}\left(\mu-\mathrm{SCHPh}_{2}\right)_{2}(\mathrm{NO})_{4}\right]$ (II) complexes and NO donor ability of complex I. 


\section{Experimental}

\subsection{Instrumental methods}

\subsubsection{X-ray diffraction experiments}

Crystal structures of I and II were determined by the means of single crystal X-ray diffraction analysis. Crystals were fixed on a micro mounts, placed on a Bruker Kappa Apex II Duo diffractometer and measured at a temperature of $100 \mathrm{~K}$ using microfocused monochromated Mo K $\alpha$ radiation. Data were integrated and corrected for background, Lorentz, and polarization effects using an empirical spherical model by means of the Bruker programs APEX2 and XPREP. Extinction correction was applied using the SADABS program [28].

The unit cell parameters and refinement characteristics for the crystal structures of I and II are given in Table 1. The unit cell parameters of I were determined and refined by the least-squares techniques on the basis of 3223 reflections with $2 \theta$ in the range of $7.14-60.00^{\circ}$. From the systematic absences and statistics of reflection distribution, the space group $C 2 / m$ was determined. The structure was solved by the direct method and refined to $R_{1}=0.059$ $\left(w R_{2}=0.110\right)$ for 700 reflections with $\left|F_{o}\right| \geqslant 4 \sigma F$ using the SHELXL97 [29] incorporated in the oLEX2 program package [30]. The unit cell parameters of II were determined and refined by the least-squares techniques on the basis of 7304 reflections with $2 \theta$ in the range of $8.98-60.00^{\circ}$. From the systematic absences and statistics of reflection distribution, the space group $P \overline{1}$ was determined. The structure was solved by the direct method and refined to $R_{1}=0.047$ $\left(w R_{2}=0.120\right)$ for 3215 reflections with $\left|F_{o}\right| \geqslant 4 \sigma F$ using the SHELXL-97 program [29] incorporated in the oLEX2 program package [30]. The final models included coordinates and anisotropic displacement parameters for all non-hydrogen atoms. The carbonbound $\mathrm{H}$ atoms were placed in calculated positions and were included in the refinement in the 'rider' model approximation, with $U_{\text {iso }}(\mathrm{H})$ set to $1.5 U_{\text {eq }}(\mathrm{C})$ and $\mathrm{C}-\mathrm{H} 0.96 \AA$ for the $\mathrm{CH}_{3}$ groups, $U_{\text {iso }}(\mathrm{H})$ set to $1.2 U_{\text {eq }}(\mathrm{C})$ and $\mathrm{C}-\mathrm{H} 0.98 \AA$ for the tertiary $\mathrm{CH}$ groups, and $U_{\text {iso }}(\mathrm{H})$ set to $1.2 U_{\text {eq }}(\mathrm{C})$ and $\mathrm{C}-\mathrm{H} 0.93 \AA$ for the $\mathrm{CH}$ groups in phenyl fragments. High values of the refinement parameters and rather low bonds precision in the structural model of $\mathbf{I}$ are due to the small size of the crystals.

X-ray photoelectron (XP) parameters for complex I were recorded with a Kratos Axis Ultra electron spectrometer, a monochromated $\mathrm{Al} \mathrm{K \alpha}$ source operated at $150 \mathrm{~W}$ and a charge neutralizer was used for the measurements. The binding energy (BE) scale was referenced to the aliphatic carbon C 1s line at $285.0 \mathrm{eV}$.

\subsubsection{Spectroscopic measurements}

${ }^{1} \mathrm{H}$ NMR spectrum was recorded on the Bruker Avance III spectrometer at $400.13 \mathrm{MHz}$ in chloroform- $\mathrm{d}_{1}$. The FT-IR spectra were recorded using pellets with $\mathrm{KBr}$ in the range 4000$400 \mathrm{~cm}^{-1}$ on a Shimadzu IR-Affinity-1 spectrometer at room temperature. Elemental analysis of II was performed on Perkin Elmer 2400 Series II CHNS/O analyzer. UV-Vis spectrum was recorded at room temperature in $1 \mathrm{~cm}$ quartz cell on Shimadzu UV-1800 spectrophotometer at $1 \mathrm{~nm}$ resolution in the range from 190 to $1100 \mathrm{~nm}$ in methanol.

\subsubsection{NO-donor ability}

For the quantification of the NO amount generated in the solution by DNIC I it was registered by the sensor electrode "amiNO-700" of the Innovative Instruments system "inNO Nitric Oxide Measuring System". The NO concentration was measured

\footnotetext{
${ }^{1}$ It should be mentioned that the quality of obtained data suffers from the complexes instability under the X-ray irradiation.
}

Table 1

Crystallographic data for I and II.

\begin{tabular}{|c|c|c|}
\hline Compound & I & II \\
\hline Formula & $\mathrm{C}_{6} \mathrm{H}_{14} \mathrm{Fe}_{2} \mathrm{~N}_{4} \mathrm{O}_{4} \mathrm{~S}_{2}$ & $\mathrm{C}_{26} \mathrm{H}_{22} \mathrm{Fe}_{2} \mathrm{~N}_{4} \mathrm{O}_{4} \mathrm{~S}_{2}$ \\
\hline Crystal system & monoclinic & triclinic \\
\hline$a(\AA)$ & $11.757(12)$ & $6.4177(4)$ \\
\hline$b(\AA)$ & $13.238(12)$ & $8.7438(6)$ \\
\hline$c(\AA)$ & $5.001(5)$ & $12.6952(9)$ \\
\hline$\alpha\left(^{\circ}\right)$ & 90 & $78.329(2)$ \\
\hline$\beta\left(^{\circ}\right)$ & $103.934(18)$ & $81.846(2)$ \\
\hline$\gamma\left({ }^{\circ}\right)$ & 90 & $83.084(2)$ \\
\hline$V\left(\AA^{3}\right)$ & $755.4(13)$ & $687.51(8)$ \\
\hline Space group & $C 2 / m$ & $P \overline{1}$ \\
\hline$\mu\left(\mathrm{mm}^{-1}\right)$ & 2.205 & 1.246 \\
\hline$Z$ & 2 & 1 \\
\hline$D_{\text {calc }}\left(\mathrm{g} \mathrm{cm}^{-3}\right)$ & 1.679 & 1.522 \\
\hline Crystal size (mm) & $0.11 \times 0.05 \times 0.01$ & $0.20 \times 0.18 \times 0.05$ \\
\hline Total reflections & 3223 & 7304 \\
\hline Unique reflections & 887 & 3705 \\
\hline Angle range $2 \theta\left(^{\circ}\right)$ & $7.14-60.00$ & $8.98-60.00$ \\
\hline Reflections with $\left|F_{o}\right| \geqslant 4 \sigma_{F}$ & 700 & 3215 \\
\hline$R_{\text {int }}$ & 0.2080 & 0.0917 \\
\hline$R_{\sigma}$ & 0.1253 & 0.0691 \\
\hline$R_{1}\left(\left|F_{o}\right| \geqslant 4 \sigma_{F}\right)$ & 0.0591 & 0.0471 \\
\hline$w R_{2}\left(\left|F_{o}\right| \geqslant 4 \sigma_{F}\right)$ & 0.1101 & 0.1201 \\
\hline$R_{1}$ (all data) & 0.0750 & 0.0520 \\
\hline$w R_{2}$ (all data) & 0.1157 & 0.1231 \\
\hline$S$ & 0.991 & 1.067 \\
\hline$\rho_{\min }, \rho_{\max }\left(\mathrm{e} \AA^{-3}\right)$ & $-1.368,0.769$ & $-1.111,1.265$ \\
\hline
\end{tabular}

$R_{1}=\Sigma|| F_{o}|-| F_{c}|| / \Sigma\left|F_{o}\right| ; \quad w R_{2}=\left\{\Sigma\left[w\left(F_{o}^{2}-F_{c}^{2}\right)^{2}\right] / \Sigma\left[w\left(F_{o}^{2}\right)^{2}\right]\right\}^{1 / 2} ; \quad w=1 /\left[\sigma^{2}\left(F_{o}^{2}\right)+\right.$ $\left.(a P)^{2}+b P\right]$, where $P=\left(F_{o}^{2}+2 F_{c}^{2}\right) / 3 ; s=\left\{\Sigma\left[w\left(F_{o}^{2}-F_{c}^{2}\right)\right] /(n-p)\right\}^{1 / 2}$ where $n$ is the number of reflections and $p$ is the number of refinement parameters.

for $500 \mathrm{~s}$ with the $0.2 \mathrm{~s}$ time step in $1 \%$ DMSO water solution with the $4 \mu \mathrm{M}$ concentration of NO donor (complexes were predissolved in DSMO). For the calibration of electrochemical sensor the $100 \mu \mathrm{M} \mathrm{NaNO}{ }_{2}$ water solution was added to the $18 \mathrm{~mL}$ mixed water solution of $0.12 \mathrm{M} \mathrm{KI}$ and $2 \mathrm{~mL} 1 \mathrm{M} \mathrm{H}_{2} \mathrm{SO}_{4}$. The experiment was carried out under aerobic and anaerobic conditions at $25^{\circ} \mathrm{C}$ and $\mathrm{pH}$ values 6.5, 7.0 (physiological values) and 9.0 (for the evaluation of the $\mathrm{pH}$ effect). The $\mathrm{pH}$ was measured by HANNA instruments membrane pH-meter "HI 8314". Commercial buffer "Hydrion" was used for appropriate $\mathrm{pH}$ estimation.

\subsection{DFT calculations}

DFT calculations were performed with the PBEhVP86 functional and Dunning's triple-zeta cc-PVTZ basis set [31] (aug-cc-PVTZ for topological analysis) level of theory using GAUSSIAN 09 [32] software package. The QM approach was validated by comparison the calculated and experimental geometrical parameters for complexes; the calculated parameters matched accurately with X-ray data (Table S3). The solvent effects were accounted for in PCM model [33]. The stacking interactions were accounted for with the M062X functional [34].

\subsection{Synthesis}

All reagents were purchased from commercial sources and used without further purifications. Ethyl nitrite was prepared by the esterification reaction from ethanol and sodium nitrite. The syntheses were carried out under inert atmosphere.

\subsection{1. trans-Bis(mercapto-i-propyl- $\left.\kappa^{2} \mathrm{~S}: \mathrm{S}\right)$ bis[dinitrosyl-iron]( $\left.\mathrm{Fe}-\mathrm{Fe}\right)(\mathrm{I})$}

$2 \mathrm{~mL}$ of $\mathrm{Fe}(\mathrm{CO})_{5} \quad(14.8 \mathrm{mmol})$ and $1.4 \mathrm{~mL} \quad(15 \mathrm{mmol})$ 2-propanethiol were mixed in $5 \mathrm{~mL}$ of deaerated ethanol and left for several hours at $4{ }^{\circ} \mathrm{C}$ for system equilibration. No reaction was observed. After the solution was cooled to $-40{ }^{\circ} \mathrm{C} 2 \mathrm{~mL}$ (21 mmol) of ethyl nitrite was added during next $10 \mathrm{~min}$. During the reaction a microcrystalline precipitate was formed. After $3 \mathrm{~h}$ 
the precipitate was collected, washed twice with $7 \% \mathrm{HCl}$ (to remove the traces of the iron oxides formed on the crystals surface) and water. The product was crystallized from $n$-hexane at ambient temperature until the plate burgundy-colored crystals suitable for $\mathrm{X}$-ray analysis were formed. Product yield $\sim 55 \%$.

Anal. Calc. for $\mathrm{C}_{6} \mathrm{H}_{14} \mathrm{Fe}_{2} \mathrm{~N}_{4} \mathrm{O}_{4} \mathrm{~S}_{2}$ : C, 18.9; Fe, 29.2; N, 14.7; S, 16.8. Found: C, 19.4; Fe, 29.5; N, 13.4; S, 17.2\%.

IR $(\mathrm{KBr}) v, \mathrm{~cm}^{-1}: 442,557,613,1047,1142,1234,1369,1381$, 1439, 1458, 1717 ( $\left.v_{\mathrm{NO}}\right), 1790\left(v_{\mathrm{NO}}\right), 2857,2920,2955$ and 2984.

UV-Vis, $\lambda_{\max }\left(\mathrm{cm}^{-1} \cdot \mathrm{M}^{-1}\right)$, nm: 240, 310 (10820), 360 (10000) and 435.

${ }^{1} \mathrm{H}$ NMR, $\delta$, ppm: $1.56(\mathrm{~s}, 1 \mathrm{H}, \mathrm{CH}), 3.01\left(\mathrm{~s}, 6 \mathrm{H}, \mathrm{CH}_{3}\right)$.

XPS, $E_{B E}$, eV: C $1 s 285.0$ ( $-\mathrm{CH}_{2}-$ ), S 2 $p_{3 / 2} 162.9$ ( $\left.\mu-S R\right), \mathrm{N} 1 \mathrm{~s} 401.3$ $(N=0)$, O 1 s $533.3(\mathrm{~N}=0){ }^{2}$ Fe $2 p_{3 / 2}$ 709.4.

\subsection{2. trans-Bis(mercapto-diphenylmethyl- $\kappa^{2}$ S:S)bis[dinitrosyliron] $(\mathrm{Fe}-\mathrm{Fe})(\boldsymbol{I I})$}

Complex II was prepared similarly to compound I. Product yield $\sim 60 \%$. The diphenylmethyl thiol bridging ligand was prepared from the diphenylmethanol and Lawesson's reagent according to $[36,37]$ and purified by the fractional distillation $\left(\sim 150^{\circ} \mathrm{C}\right.$, 10 Torr).

Anal. Calc. for $\mathrm{C}_{26} \mathrm{H}_{12} \mathrm{Fe}_{2} \mathrm{~N}_{4} \mathrm{O}_{4} \mathrm{~S}_{2}$ : C, 49.6; Fe, 17.7; N, 8.9; S, 10.2. Found: C, 50.0; Fe, 18.1; N, 8.3; S, 11.5\%.

IR (KBr) $v, \mathrm{~cm}^{-1}:$ 625, 697, 748, 1449, $1728\left(v_{\mathrm{NO}}\right)$ и $1775\left(v_{\mathrm{NO}}\right)$.

\section{Results and discussion}

Here we describe the "one-pot" synthesis and crystal structure of DNIC with iso-propyl and benzhydryl substituents at bridging thiolate ligand ( $\mu$-SR) (Fig. 1 ). The compounds were obtained by treatment of the mixture of iron pentacarbonyl with the corresponding thiol followed by addition of ethyl nitrite under inert atmosphere. ${ }^{3}$ The formation of Roussin's red salt ester probably occurs via the stage of intermediate iron dinitrosyldicarbonyl $\mathrm{Fe}(\mathrm{NO})_{2}(\mathrm{CO})_{2}$ generation; this nitrosylated precursor is known to give DNICs when reacted with thiols $[12,26]$ or with nitrogen containing bidentate aromatic ligands [38,39]. The advantage of ethyl nitrite consists in the mild conditions $\left(4^{\circ} \mathrm{C}\right)$ of the nitrosylation reaction and the easy control of the amount of NO-source.

The Fe...Fe distance $2.711 \AA$ in $\left[\mathrm{Fe}_{2}\left(\mu-\mathrm{S}^{i} \mathrm{Pr}\right)_{2}(\mathrm{NO})_{4}\right]$ complex is longer than in DNICs with methyl and ethyl thiolate ligands (2.686 and 2.708 $\AA$ ) (Table S2), but matches the value for complex with tertiary $\mu-S^{t} \mathrm{Bu}$ bridging ligand. In the second $\left[{ }^{\prime} \mathrm{Fe}_{2}(\mu-\right.$ 'SCHPh $\left.{ }_{2}\right)_{2}\left({ }^{\prime} \mathrm{N}^{\prime} \mathrm{O}\right)_{4}$ ] complex the $\mathrm{Fe}^{\prime}$.... $\mathrm{Fe}^{\prime}$ distance is extended up to $2.730 \AA$, compared to reported DNIC with benzylthiolate bridging ligand $2.712 \AA$ [19]. ${ }^{4}$ We have analyzed the Mulliken charge distribution for RRSE with different substituents on thiolate sulfur (Table S1). Replacing hydrogens in $\left[\mathrm{Fe}_{2}\left(\mu-\mathrm{SCH}_{3}\right)_{2}(\mathrm{NO})_{4}\right]$ with Me groups up to ${ }^{i} \mathrm{Pr}$ leads to the increase in the negative charge on sulfur and decrease in the positive charge on Fe atoms. In case of ${ }^{t} \mathrm{Bu}$ the negative charge on sulfur increases, but iron gets more positive value compared even with $\mu-\mathrm{SCH}_{3}$. The hydrogen substitution with aromatic phenyl rings results in stronger charge changes on the $\mathrm{Fe}$ and $\mathrm{S}$ core atoms, but with the same tendency. The complex with trityl substituent $\left[\mathrm{Fe}_{2}\left(\mu-\mathrm{SPh}_{3}\right)_{2}(\mathrm{NO})_{4}\right]$ has the highest bond polarity compared to other complexes in Table $\mathrm{S} 2$.

\footnotetext{
2 That value is close to the iron in $\left[\mathrm{Fe}_{2}(\mu-\mathrm{SR})_{2}(\mathrm{NO})_{4}\right]$ complex studied by Brant $709.2 \mathrm{eV}$ [35].

${ }^{3}$ We have also prepared the complex with benzylthiolate ligand $\left[\mathrm{Fe}_{2}(\mu-\mathrm{SBn})_{2}\right.$ $\left.(\mathrm{NO})_{4}\right]$ applying the same reaction conditions. The complex crystallized with the same cell parameters as in earlier published paper [19], but with $0.39 \%$ smaller $R$-factor (crystallographic data are presented in Table S4).

4 The comparison of geometrical parameters with previously synthesized com-
} plexes can be founds it Table S1 of Supporting information.
Since DNICs can be formed in living cells and then serve as nitric oxide depot, the NO donor ability was studied for the $\left[\mathrm{Fe}_{2}\left(\mu-\mathrm{S}^{i} \mathrm{Pr}\right)_{2}(\mathrm{NO})_{4}\right]$ complex (DNIC with $\left(\mu-\mathrm{SCHPh}_{2}\right)$ bridging ligand was not studied due to its extremely low solubility). DNIC I generates NO in protic media without photo or thermal activation. It is shown that with the $\mathrm{pH}$ rise from 6.5 to 9.0 the amount of evolved NO decreases almost twice. As it can be seen from experimental curve of equilibrated amount of NO versus time after compound I dissolution (Fig. 2) the maximal NO donation was achieved at anaerobic conditions with pH 6.5 value after $500 \mathrm{~s}$.

In aerobic conditions, the NO amount and kinetic relationships are close to those in anaerobic solutions. The complex for a long time donates NO in water solution, presumably, because of the formation of relatively stable intermediates. With the rise of $\mathrm{pH}$ to 7.0 the character of the kinetic curves changes. For the first $50 \mathrm{~s}$ the complex evolves NO in smaller amounts $(\sim 0.5 \mathrm{nM})$, then more extensive nitric oxide generation begins and after $100 \mathrm{~s}$ the amount of $\mathrm{NO}(\sim 4.0 \mathrm{nM})$ is close to the value at $\mathrm{pH} 6.5$ $(\sim 6.0 \mathrm{nM})$; but then the curve reaches the plateau compared to the experiment at $\mathrm{pH} 6.5$, where the $\mathrm{NO}$ prolonged generation takes place [40].

In comparison with water-soluble DNICs with cysteamine bridging ligand $\left[\mathrm{Fe}_{2}\left(\mu-\mathrm{SCH}_{2} \mathrm{CH}_{2} \mathrm{NH}_{3}\right)_{2}(\mathrm{NO})_{4}\right] \mathrm{SO}_{4}$ [41] or mononuclear DNICs with thiourea [ $\left.\mathrm{Fe}\left(\mathrm{SC}\left(\mathrm{NH}_{2}\right)_{2}\right)_{2}(\mathrm{NO})_{2}\right] \mathrm{Cl}$ [10] complex I evolves NO less actively; that could originate from the solvation effects.

\section{Theoretical studies}

The initial geometry for calculations was taken directly from the resolved crystal structures; normal mode vibration analysis was performed to prove that the optimized structures are in the local minima.

DNIC with ${ }^{i} \mathrm{Pr}$ bridging thiolate ligand was earlier studied by solution ${ }^{15} \mathrm{~N}$ and ${ }^{13} \mathrm{C}$ NMR [42]. NMR data showed that $\left[\mathrm{Fe}_{2}\left(\mu-\mathrm{SCHMe}_{2}\right)_{2}(\mathrm{NO})_{4}\right]$ exist in solution in two equimolar isomeric forms: cis-conformer ( $C_{2 v}$ symmetry) and trans-conformer $\left(C_{2 h}\right.$ symmetry).

We have tested the cis-conformers of the complexes under the current study. The calculated energy differences between two isomeric forms in gas state: the ${ }^{\text {gas }} \Delta E=E_{\text {trans }}-E_{\text {cis }}$ for complex I is $0.3 \mathrm{~kJ} / \mathrm{mol}$ and $0.8 \mathrm{~kJ} / \mathrm{mol}$ for II. The values indicate very small preference of the trans-isomeric form. The difference in aqueous medium (accounted for by means of the PCM model) water $\Delta E$ has an opposite character -0.4 and $-1.6 \mathrm{~kJ} / \mathrm{mol}$, the reason of that difference is that $C_{2 v}$ molecules have larger value of solvation energy compared to $C_{2 h}$ symmetry conformers. The larger solvation value can lead to more effective NO release from $C_{2 v}$ complex (substitution of nitrosyl ligand by water molecule). Nevertheless, this assumption should be examined in further experimental studies.

The diamagnetism (supported by NMR data) of $\left[\mathrm{Fe}_{2}\left(\mu-\mathrm{CHMe}_{2}\right)_{2}\right.$ $\left.(\mathrm{NO})_{4}\right]$ and $\left[\mathrm{Fe}_{2}\left(\mu-\mathrm{SCHPh}_{2}\right)_{2}(\mathrm{NO})_{4}\right]$ indicates that the complexes exist in a singlet magnetic state. The $\left[\mathrm{Fe}_{2}(\mu-\mathrm{SR})_{2}(\mathrm{NO})_{4}\right]$ can be represented as the combination of two $\left\{\mathrm{Fe}(\mathrm{NO})_{2}\right\}^{9}-\left\{\mathrm{Fe}(\mathrm{NO})_{2}\right\}^{9}$ units according to the Enemark-Feltham notation [43], the spinspin coupling proceeds via thiolate ( $\mu$-SR) bridges.

In complex II crystal structure conformation is stabilized by stacking interactions between two pare of phenyl rings in the [101] direction $(r=3.510 \AA$ ). The intermolecular $\pi$-stacking interaction energy was accounted as the difference of the total energies of the two-molecule complex and a single one and was found to be $\sim 19.2 \mathrm{~kJ} / \mathrm{mol}$. The calculated energy is close to the experimental values [44]. Furthermore, the conformation of II can be stabilized by the phenyl ring hydrogen and nitrosyl ligand oxygen short contacts (see Fig. S5). 


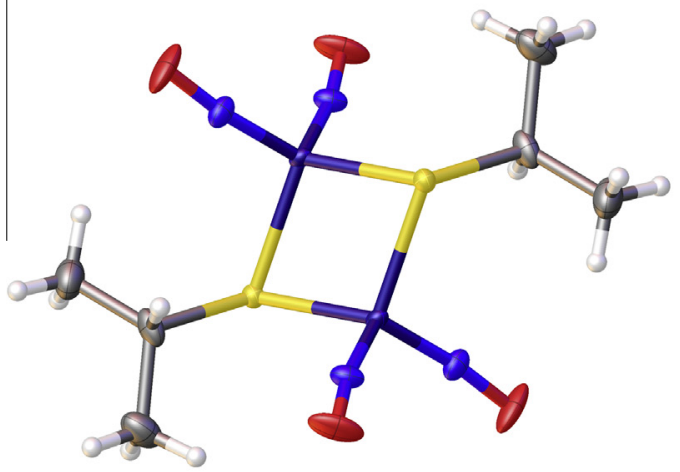

(a)

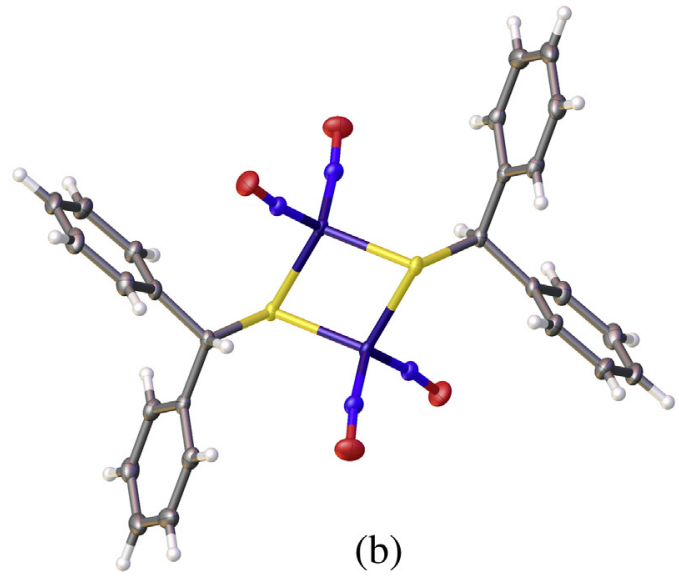

(b)

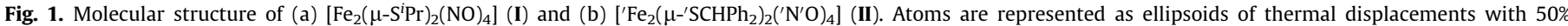

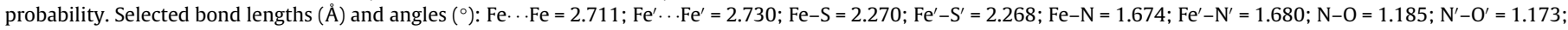
$\checkmark \mathrm{Fe}-\mathrm{N}-\mathrm{O}=169.44 ; \quad<\mathrm{Fe}^{\prime}-\mathrm{N}^{\prime}-\mathrm{O}^{\prime}=170.90$.

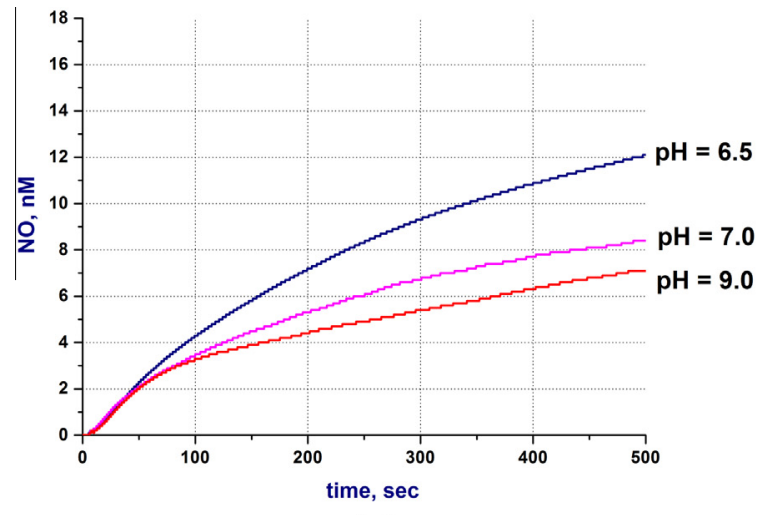

(a)

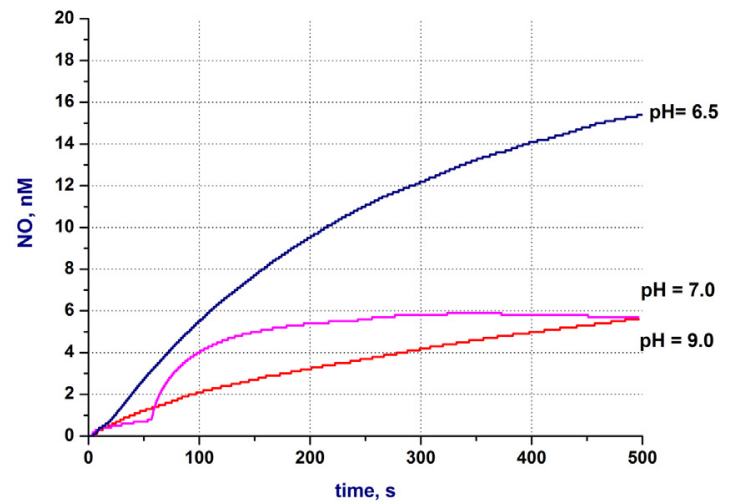

(b)

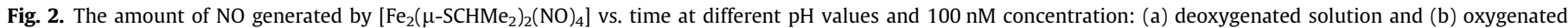
solution.

Accumulation of information on the synthetic method and structure of RRSE with different substituents in thiolate bridges is important for understanding the structure-property relationship in RRSE, as the complexes are suggested as promising prodrugs. Further findings could bring the contribution to the understanding of the RRSE structure-property relationships.

\section{Acknowledgments}

The work has been supported by the Ministry of Education and Science of the Russian Federation (State Contract 14.B25.310013) and the Program of the Presidium of RAS "Fundamental sciences for medicine". XRD study has been prepared at the X-ray Diffraction Centre of Saint-Petersburg State University. NMR studies were performed by S. Smirnov at the Centre for Magnetic Resonance of Saint-Petersburg State University.

\section{Appendix A. Supplementary data}

CCDC 991969 and 991970 contains the supplementary crystallographic data for complex I and II. These data can be obtained free of charge via http://www.ccdc.cam.ac.uk/conts/retrieving.html, or from the Cambridge Crystallographic Data Centre, 12 Union Road, Cambridge CB2 1EZ, UK; fax: (+44) 1223336 033; or e-mail: deposit@ccdc.cam.ac.uk. Supplementary data associated with this article can be found, in the online version, at http://dx.doi.org/10. 1016/j.poly.2015.02.009.

\section{References}

[1] D.C. Johnson, D.R. Dean, A.D. Smith, M.K. Johnson, Annu. Rev. Biochem. 74 (2005) 247.

[2] I. Romero-Canelón, P.J. Sadler, Inorg. Chem. 52 (2013) 12276.

[3] J.C. Crack, L.J. Smith, M.R. Stapleton, J. Peck, N.J. Watmough, M.J. Buttner, R.S. Buxton, J. Green, V.S. Oganesyan, A.J. Thomson, N.E. Le Brun, J. Am. Chem. Soc. 133 (2010) 1112.

[4] T.C. Harrop, Z.J. Tonzetich, E. Reisner, S.J. Lippard, J. Am. Chem. Soc. 130 (2008) 15602.

[5] L. Grossi, P.C. Montevecchi, Chem.-Eur. J. 8 (2002) 380.

[6] J.M. Joslin, B.H. Neufeld, M.M. Reynolds, RSC Adv. 4 (2014) 42039.

[7] T.C. Berto, A.L. Speelman, S. Zheng, N. Lehnert, Coord. Chem. Rev. 257 (2013) 244.

[8] K.A. Broniowska, N. Hogg, Antioxid. Redox Signal. 17 (2012) 969.

[9] J.C. Crack, J. Green, A.J. Thomson, N.E.L. Brun, Acc. Chem. Res. 47 (2014) 3196.

[10] N.A. Sanina, S.M. Aldoshin, N.Y. Shmatko, D.V. Korchagin, G.V. Shilov, N.S Ovanesyan, A.V. Kulikov, Inorg. Chem. Commun. 49 (2014) 44.

[11] Q. Zheng, A. Bonoiu, T.Y. Ohulchanskyy, G.S. He, P.N. Prasad, Mol. Pharm. 5 (2008) 389.

[12] S.A.T. Dillinger, H.W. Schmalle, T. Fox, H. Berke, Dalton Trans. (2007) 3562.

[13] T.N. Rudneva, N.A. Sanina, K.A. Lyssenko, S.M. Aldoshin, M.Y. Antipin, N.S. Ovanesyan, Mendeleev Commun. 19 (2009) 253.

[14] D. Seyferth, M.K. Gallagher, M. Cowie, Organometallics 5 (1986) 539.

[15] N.A. Sanina, A.G. Krivenko, R.A. Manzhos, N.S. Emelyanova, G.I. Kozub, D.V. Korchagin, G.V. Shilov, T.A. Kondrateva, N.S. Ovanesyan, S.M. Aldoshin, New J. Chem. 38 (2014) 292.

[16] J. Fitzpatrick, H. Kalyvas, J. Shearer, E. Kim, Chem. Commun. 49 (2013) 5550.

[17] P.B. Davidovich, V.V. Gurzhy, A.N. Belyaev, Russ. J. Gen. Chem. 84 (2014) 719. 
[18] Z.J. Tonzetich, H. Wang, D. Mitra, C.E. Tinberg, L.H. Do, F.E. Jenney, M.W.W Adams, S.P. Cramer, S.J. Lippard, J. Am. Chem. Soc. 132 (2010) 6914.

[19] T.C. Harrop, D. Song, S.J. Lippard, J. Inorg. Biochem. 101 (2007) 1730

[20] Z. Lin, F. Lo, C. Li, C. Chen, W. Huang, I. Hsu, J. Lee, J. Horng, W. Liaw, Inorg. Chem. 50 (2011) 10417.

[21] N.A. Sanina, O.A. Rakova, S.M. Aldoshin, I.I. Chuev, E.G. Atovmyan, N.S Ovanesyan, Russ. J. Coord. Chem. 27 (2001) 179

[22] T.C.W. Mak, L. Book, C. Chieh, M.K. Gallagher, L. Song, D. Seyferth, Inorg. Chim. Acta 73 (1983) 159

[23] R. Wang, M.A. Camacho-Fernandez, W. Xu, J. Zhang, L. Li, Dalton Trans. (2009) 777.

[24] Y.-J. Chen, W.-C. Ku, L.-T. Feng, M.-L. Tsai, C.-H. Hsieh, W.-H. Hsu, W.-F. Liaw, C.-H. Hung, Y.-J. Chen, J. Am. Chem. Soc. 130 (2008) 10929.

[25] C.-C. Tsou, W.-F. Liaw, Chem.-Eur. J. 17 (2011) 13358.

[26] T.C. Harrop, D. Song, S.J. Lippard, J. Am. Chem. Soc. 128 (2006) 3528.

[27] T.-T. Lu, C.-C. Tsou, H.-W. Huang, I.J. Hsu, J.-M. Chen, T.-S. Kuo, Y. Wang, W.-F. Liaw, Inorg. Chem. 47 (2008) 6040.

[28] G.M. Sheldrick, SADABS, University of Göttingen, Germany, 2004

[29] G. Sheldrick, Acta Crystallogr., Sect. A 64 (2008) 112.

[30] O.V. Dolomanov, L.J. Bourhis, R.J. Gildea, J.A.K. Howard, H. Puschmann, J. Appl. Crystallogr. 42 (2009) 339.

[31] T.H. Dunning, K.A. Peterson, A.K. Wilson, J. Chem. Phys. 114 (2001) 9244.

[32] Gaussian 09, Revision D01, M.J. Frisch, G.W. Trucks, H.B. Schlegel, G.E. Scuseria, M.A. Robb, J.R. Cheeseman, G. Scalmani, V. Barone, B. Mennucci, G.A. Petersson, H. Nakatsuji, M. Caricato, X. Li, H.P. Hratchian, A.F. Izmaylov, J. Bloino, G. Zheng, J.L. Sonnenberg, M. Hada, M. Ehara, K. Toyota, R. Fukuda, J. Hasegawa, M. Ishida, T. Nakajima, Y. Honda, O. Kitao, H. Nakai, T. Vreven, J.A
Montgomery, J.E. Peralta, F. Ogliaro, M. Bearpark, J.J. Heyd, E. Brothers, K.N. Kudin, V.N. Staroverov, R. Kobayashi, J. Normand, K. Raghavachari, A. Rendell, J.C. Burant, S.S. Iyengar, J. Tomasi, M. Cossi, N. Rega, J.M. Millam, M. Klene, J.E. Knox, J.B. Cross, V. Bakken, C. Adamo, J. Jaramillo, R. Gomperts, R.E. Stratmann, O. Yazyev, A.J. Austin, R. Cammi, C. Pomelli, J.W. Ochterski, R.L. Martin, K. Morokuma, V.G. Zakrzewski, G.A. Voth, P. Salvador, J.J. Dannenberg, S. Dapprich, A.D. Daniels, Farkas, J.B. Foresman, J.V. Ortiz, J. Cioslowski, D.J. Fox, Gaussian Inc., Wallingford CT, 2009.

[33] Y. Takano, K.N. Houk, J. Chem. Theory Comput. 1 (2004) 70.

[34] Y. Zhao, D.G. Truhlar, Acc. Chem. Res. 41 (2008) 157.

[35] P. Brant, R.D. Feltham, Inorg. Chem. 19 (1980) 2673.

[36] T. Nishio, J. Chem. Soc., Chem. Commun. (1989) 205.

[37] M. Ohno, M. Miyamoto, K. Hoshi, T. Takeda, N. Yamada, A. Ohtake, J. Med. Chem. 48 (2005) 5279

[38] R. Wang, X. Wang, E.B. Sundberg, P. Nguyen, G.P.G. Grant, C. Sheth, Q. Zhao, S. Herron, K.A. Kantardjieff, L. Li, Inorg. Chem. 48 (2009) 9779.

[39] K.M. Skodje, P.G. Williard, E. Kim, Dalton Trans. 41 (2012) 7849.

[40] N.A. Sanina, G.I. Kozub, T.A. Kondrateva, D.V. Korchagin, G.V. Shilov, N.S. Emelyanova, R.A. Manzhos, A.G. Krivenko, S.M. Aldoshin, J. Mol. Struct. 1075 (2014) 159.

[41] N.A. Sanina, K.A. Lysenko, O.S. Zhukova, T.N. Rudneva, N.S. Emelianova, S.M. Aldoshin, U.S. Patent: 2010/0190850 A1, 2010.

[42] A.R. Butler, C. Glidewell, A.R. Hyde, J. McGinnis, Inorg. Chem. 24 (1985) 2931.

[43] J.H. Enemark, R.D. Feltham, Coord. Chem. Rev. 13 (1974) 339.

[44] B.B. Averkiev, A.A. Korlyukov, M.Y. Antipin, A.B. Sheremetev, T.V. Timofeeva, Cryst. Growth Des. 14 (2014) 5418 